\title{
Attitudes towards carnivores: the views of emerging commercial farmers in Namibia
}

\author{
B. Schumann, J. L. Walls and V. Harley
}

\begin{abstract}
The emerging commercial farmers in Namibia represent a new category of farmer that has entered the freehold farming sector since Namibia's independence in 1990. Several assessments of agricultural training needs have been carried out with these farmers but the issue of humancarnivore conflict has not yet been addressed. This study investigated one of the key components driving humancarnivore conflict, namely the attitudes of these farmers towards carnivores and how this affects the level of conflict and carnivore removal. We observed that the attitudes of these farmers are similar to farmers elsewhere. In general, farmers reported high levels of human-carnivore conflict. Many farmers perceived that they had a carnivore problem when sighting a carnivore or its tracks, even in the absence of verified carnivore depredation. Such sightings were a powerful incentive to prompt farmers to want to take action by removing carnivores, often believed to be the only way to resolve human-carnivore conflict. Nonetheless, our study showed that farmers who understood that carnivores play an ecological role had a more favourable attitude and were less likely to want all carnivores removed. We found that negative attitudes towards carnivores and loss of livestock, especially of small stock, predicted actual levels of humancarnivore conflict. Goat losses additionally predicted actual carnivore removals. We discuss the implications of our findings in relation to the activities of support structures for emerging commercial farmers in Namibia.
\end{abstract}

Keywords Attitudes, emerging commercial farmer, human-carnivore conflict, Namibia, perceptions

\section{Introduction}

T uman-wildlife conflict is defined by Conover (2002) 1 as any action by humans or wildlife that has an adverse impact on the other. Carnivores in particular come into direct or indirect conflict with humans by posing a threat to human life and/or economic stability (Conover, 1994; Sillero-Zubiri \& Laurenson, 2001; Woodroffe, 2001;

B. SCHumann (Corresponding author)* and V. Harley Cape Peninsula University of Technology, Cape Town, South Africa. E-mail bonnieschumann@yahoo.com

J.L. Walls Concordia University, Montreal, Canada

${ }^{*}$ Current address: P.O. Box 172, Loxton, 6985, South Africa

Received 22 November 2010. Revision requested 20 January 2011. Accepted 5 April 2011.
Ogada et al., 2003; Treves \& Karanth, 2003; Thirgood et al., 2005). Despite intensive conservation efforts, carnivore species overall are on the decline and population extinctions continue (Sillero-Zubiri \& Laurenson, 2001; Woodroffe, 2001). Yet carnivore species play a pivotal role in ecosystem function, making their conservation a priority (Gittleman et al., 2001; Sillero-Zubiri \& Laurenson, 2001; Treves \& Karanth, 2003).

Human-carnivore conflict is associated with a complex set of factors, including attitudes and perceptions (SilleroZubiri \& Laurenson, 2001; James, 2002; Dickman, 2005). In general, attitudes refer to the degree of positive or negative feelings people associate with some psychological object such as a symbol, phrase, institution, ideal or person (Thurstone, 1946). Thus, positive attitudes reflect what people 'like' and negative attitudes are things people 'dislike'; these can be captured by asking people directly how they feel (Edwards, 1994). In addition to this affective component that captures people's feelings, attitudes also contain a cognitive component that captures an attribute or belief about a particular object (Thurstone, 1928). When both of these attitude components match, they accurately predict human behaviour (Miller \& Tesser, 1986).

Attitudes towards carnivores have been studied and linked to demographic factors such as age, sex, level and source of income, religious beliefs and culture (Kellert, 1985; Kellert \& Berry, 1987; Sillero-Zubiri \& Laurenson, 2001; Dickman, 2005; Romaňach et al., 2007; Røskaft et al., 2007). Although a useful starting point, demographic perspectives on attitudes fail to specify deeper mechanisms of environmental attitudes generally, which have been shown to contain cognitive and affective components (Hines et al., 1987; Stern et al., 1993, 1995; Gagnon Thompson \& Barton, 1994; Dietz et al., 1998). Attitudes towards carnivores are partly based on the degree to which carnivores clash with human interests and partly on inherent human prejudices (Bjerke \& Kaltenborn, 1999; Lindsey et al., 2005). For instance, Sillero-Zubiri \& Laurenson (2001) found that predation by carnivores on livestock was a prevalent predictor of human-carnivore conflict. However, attitudes towards carnivores are not always directly associated with carnivore predation behaviour and must take into account human feelings towards, and beliefs about, carnivores. Kellert (1985) found that even when wolves caused little livestock depredation, sheep and cattle farmers maintained negative attitudes towards wolves. Studies concur that farmers worldwide generally believe large carnivores have no place on farmland, and fail to appreciate their ecological 
role (Kellert, 1985; Conover, 1994; Oli et al., 1994). Equally, in Africa, local people such as domestic stock farmers, pastoralists and much of the rural population view carnivores as a nuisance and see little ecological, aesthetic or financial value in them (Marker et al., 1996; Stander et al., 1997; Dickman, 2005).

In Namibia $90 \%$ of the 3,000 strong cheetah Acinonyx jubatus population survives on privately owned farmland in the north-central cattle-ranching region (Marker, 2002). In addition, carnivores such as the leopard Panthera pardus, brown hyaena Hyaena brunnea, jackal Canis mesomelas, caracal Felis caracal and, in some cases, lion Panthera leo, spotted hyaena Crocuta crocuta and African wild dog Lycaon pictus share this farmland (Marker et al., 1996; Hanssen \& Stander, 2004). Research into human-carnivore conflict on freehold farmland in Namibia has focused mainly on formerly advantaged commercial farmers (Marker et al., 1996; Marker \& Schumann, 1998; Marker, 2002; Schumann, 2006; Schumann et al., 2008). While these farmers were the majority freehold landowners until Namibia's independence in 1990, land reform initiatives since then have led to a drastic demographic change in the farming community.

Formerly disadvantaged Namibians have moved onto freehold farmland, aided by the Affirmative Action Loan Scheme. Many of these farmers have no formal agricultural training and are hampered by a lack of skills and knowledge necessary to run a commercial operation (Vigne \& Motinga, 2005). Although several assessments of agricultural training needs have been carried out for these farmers (Blackie, 1999; Desert Research Foundation of Namibia, 2005; Vigne \& Motinga, 2005), none have addressed human-carnivore conflict issues and nothing is known about their attitudes towards carnivores. Successful resource management is becoming increasingly dependent upon knowledge about how conflicts are constructed, and this entails identifying attitudes and beliefs held by various interest groups (Kaltenborn et al., 1998). Taking the aspirations and needs of specific cultural groups into account facilitates the development of appropriate human-carnivore conflict management strategies (SilleroZubiri \& Laurenson, 2001; Treves \& Karanth, 2003; Dickman, 2005). Understanding attitudes towards carnivores is thus one of the first steps towards mitigating human-carnivore conflict to ensure the survival of carnivores on freehold farmland.

Our aim here is to investigate the attitudes of emerging commercial farmers in Namibia and how these affect human-carnivore conflict. We begin by assessing the attitudes of farmers towards carnivores by measuring both affective and cognitive components. Next, we identify how farmers' perceptions of human-carnivore conflict relate to their behaviour (actions). Finally, we determine how affective and cognitive components of farmers' attitudes are associated with the level of carnivore removal.

\section{Study area}

The study area comprises the north-central freehold farmland in Namibia (Fig. 1). Mean annual rainfall is $467 \mathrm{~mm}$ and temperatures vary from $<0{ }^{\circ} \mathrm{C}$ in winter to $>50^{\circ} \mathrm{C}$ in summer (Marker, 2002). Vegetation is characterized by thorn bush, highland and camel thorn savannah (Byers, 1997), much of which is encroached by bush because of the suppression of veld fire, the absence of megaherbivores, and overgrazing and poor livestock management (Lange et al., 1997). The northern limits of the study area merge with mountain savannah and Karstveld around Tsumeb, Grootfontein and Otavi. Highland savannah in the south of the study area covers the Khomas Hochland and Windhoek bergland up to Rehoboth (Byers, 1997; Strohbach-Fricke, 1997). In these areas cattle are raised for beef production, with sheep, goats and wildlife supplementing incomes (Erb, 2004).

Our study area falls within a key livestock production area that is also regarded as a key area for wildlife (Krugmann, 2001; Erb, 2004), including the full guild of Namibia's large carnivores (Marker et al., 1996; Hanssen \& Stander, 2004). Wildlife resource management outside communal and protected areas on freehold farmland is the domain of the Ministry of Environment and Tourism, sub-division Wildlife Utilisation and Permit Control, with the focus on administering wildlife quotas, live sales and other consumptive uses (Erb, 2004).

\section{Methods}

\section{Sample and descriptive statistics}

For the purpose of this study the term emerging commercial farmer incorporates all formerly disadvantaged farmers on freehold land and excludes communal farmers living on government land. A random sample of 82 emerging commercial farmers was surveyed. Emerging commercial farmers comprise several cultural groups, identified here by respondents' home language (most commonly spoken while growing up): Herero (47.6\%), Ovambo (20.7\%), Damara (18.3\%), Afrikaans (8.5\%) and other languages (4.9\%). The majority of respondents were male (90.2\%). Female respondents were farm owners or represented their fathers or husbands. Where possible we interviewed the farm owner (64.6\%), but in some instances a representative such as the farm foreman $(19.5 \%)$ or a relative sharing the farming responsibilities (15.9\%) was questioned. Farmers had spent a mean of $6.2 \pm$ SD 4.6 years (range 1-24) living on their farms. Mean farm size was 4,682 \pm SD 2,066 ha (range 304-11,00o). The farms are in eight regions of 11 districts, with the 


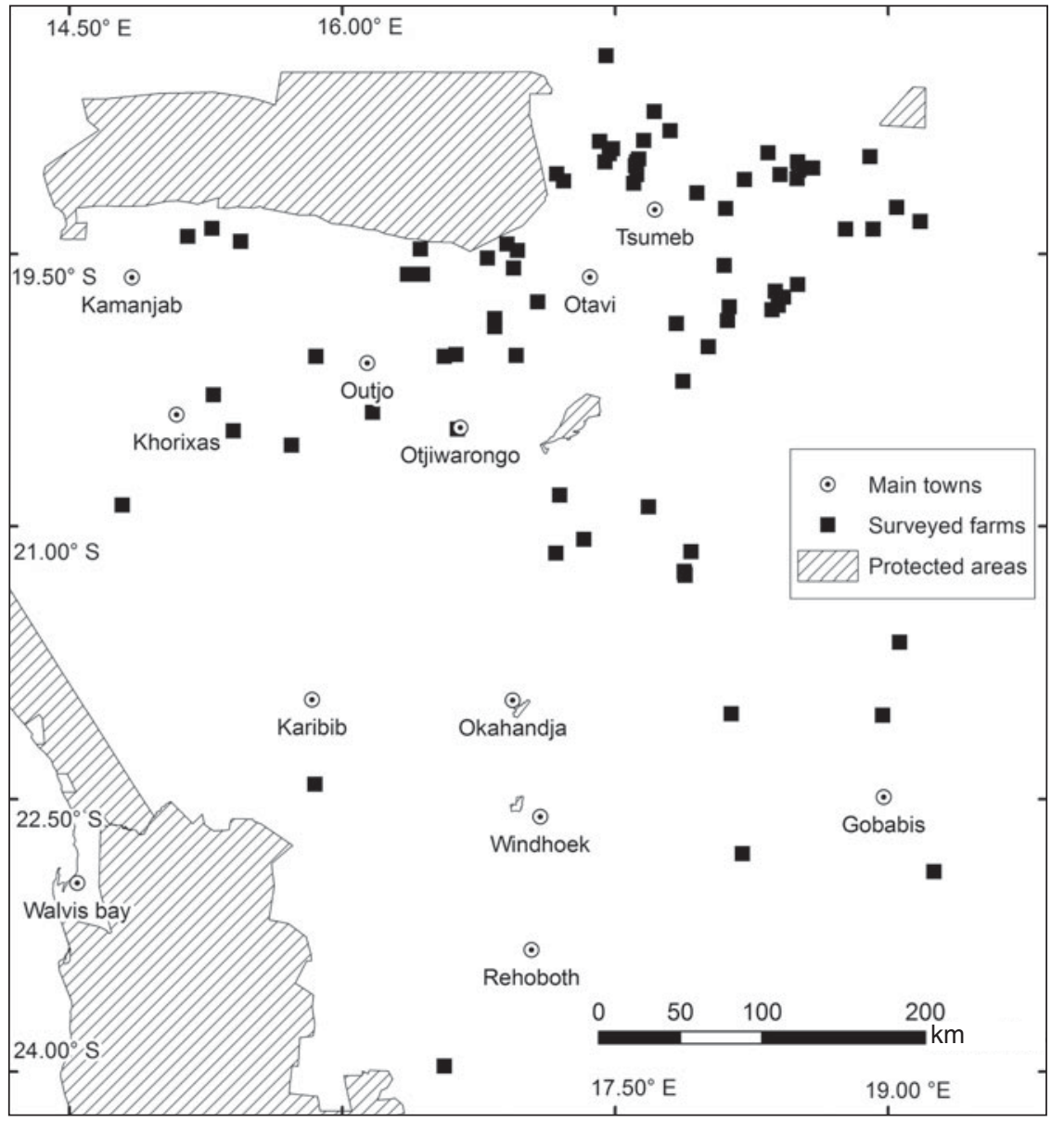

FIg. 1 The locations of respondents' farms and protected areas in the northcentral freehold farmland of Namibia. majority of farms in the Grootfontein district. One farm is in the Rundu district and, although on communal land, is a demarcated fenced farm to which the owner has title deeds.

Many of the emerging commercial farmers (48.8\%) acquired their farms through the market-based Affirmative Action Loan Scheme model whereby the Namibian government provides financial support to allow people to buy farms, thus encouraging the emergence of African entrepreneurs (Sachikonye, 2004). Vigne \& Motinga (2005) reported the majority of Affirmative Action Loan Scheme farmers they surveyed were aged $36-50$ and that most such farmers sold small stock to maintain cash flow but indicated they were attempting to move towards an oxcow production system. Some $98.8 \%$ of farmers in our study rated cattle as an important source of cash income, followed by goats ( $84.8 \%$ ) and sheep ( $75.6 \%$ ), and $53.3 \%$ of the farmers rated employment off the farm as an important source of cash income. Most farmers practised a mixed livestock farming strategy (84.1\%) comprising on average $41.0 \%$ cattle, $35.2 \%$ goats and $23.8 \%$ sheep.

\section{Survey methodology}

Interviews were conducted during 2006 by BS or by one of four staff members of a local NGO, using a questionnaire.
To refine survey items a pilot survey was carried out. Farmers were accessed at training courses, information days and agricultural shows. The results described here are part of a larger study conducted on the needs of emerging commercial farmers in Namibia in relation to humancarnivore conflict. We used a Likert (sliding) scale to assess farmers' attitudes, perceptions and behaviours (Dillman, 1991; Foddy, 1993). We assessed the farmers' ability to identify carnivores by showing them colour photographs of eight carnivores found on Namibian farmland. Farmers were asked to name carnivores in English or their own language.

\section{Operationalization of variables}

To assess attitudes towards carnivores we followed similar approaches to earlier research (Kaltenborn et al., 1998; Røskaft et al., 2007). We measured affective and cognitive attitudes towards carnivores by asking farmers to indicate how much they agreed or disagreed on a scale of 1-5 $(1=$ strongly disagree, $5=$ strongly agree $)$ with four statements (Table 1).

We measured farmers' perceptions of the level of carnivore conflict that existed on their farms. Several 
TABLE 1 The four measurement items relating to respondents' attitudes towards carnivores. In a principal component analysis with Varimax rotation items pertaining to affective and cognitive aspects of attitude loaded together on one factor, with positive and negative attitudes in opposing directions.

\begin{tabular}{ll}
\hline $\begin{array}{l}\text { Items pertaining to respondents' perceptions } \\
\text { of carnivores }\end{array}$ & $\begin{array}{l}\text { Factor } \\
\text { loadings }\end{array}$ \\
\hline $\begin{array}{l}\text { I want all carnivores removed off farmland \& living } \\
\text { only in reserves such as Etosha National Park }\end{array}$ & 0.89 \\
$\begin{array}{l}\text { The only way I can reduce losses is to remove all } \\
\text { carnivores from my farm }\end{array}$ & 0.85 \\
$\begin{array}{l}\text { Carnivores have an ecological role to play on my } \\
\text { farm }\end{array}$ & -0.81 \\
\begin{tabular}{l} 
I like having carnivores on my farm \\
\hline
\end{tabular} & -0.72 \\
\hline
\end{tabular}

items were used to identify how much farmers agreed or disagreed on a five-point Likert scale with statements such as: 'When several livestock are killed, I know I have a carnivore problem' and 'When carnivores are seen, I know I have a carnivore problem'.

We measured farmers' intended behaviour by assessing when they would be likely to take action to remove carnivores from their farmland. Using the same scenarios as above, in this way facilitating the comparison of the perceived level of conflict versus farmers' behaviour in the form of removing carnivores, we asked farmers to indicate how strongly they agreed or disagreed with statements such as: 'I attempt to remove a carnivore after several livestock kills are found'.

For the regression analysis additional survey items were used. The dependent variable in the first set of regressions was the level of carnivore conflict, reported by farmers on a scale from 1 ('carnivores are no problem') to 5 ('carnivores are a very big problem'). The dependent variable in the second set of regressions was the level of carnivore removal, measured as the sum of the total number of carnivores removed from the farm in the preceding year, as reported by farmers. Regressions included a number of control variables such as length of time on the farm (years), location (longitude and latitude), farm size (in 1,000s of ha), carnivore trend (based on the farmer's perception of increase or decrease in carnivores since owning the farm), and attitude towards carnivores (aggregated measure based on the four survey items capturing farmers' attitudes towards carnivores). In the regressions including livestock loss, we included additional independent variables of interest: the size of the herd (number of livestock), whether or not the type of livestock (goats, sheep, cattle) was a source of cash income, and total loss of livestock measured as the number of livestock lost (goats, sheep, cattle, calves) in the preceding year.

\section{Data analysis}

Data were analysed using SPSS v. 12.0 (SPSS Inc., Chicago, USA). Missing and non-applicable responses were dropped from the analysis. To determine percentages, responses such as 'very important' and 'important' were combined as 'important', and 'strongly agree' and 'agree' were combined as 'agree'. The same approach was taken for negative responses. We tested for normality of variables and used the Kolmogorov-Smirnov test and non-parametric statistics where the assumptions of normality were violated. To compare distribution of data between categories we used $\chi^{2}$ tests. Correlations between and within questions containing non-parametric ordinal and nominal data with nonnormal distributions and unequal variances were examined using Spearman's $\rho$.

Principal component analyses were used to explore the structure of the data for common themes, using Varimax rotation, and loadings were assessed above a 0.50 cut-off point typically used in social science research (Bartholomew et al., 2002). The original Likert-scale responses were used to allow for maximum variance and detail. We used factor analysis as a Harman's single factor test of common method bias (Podsakoff et al., 2003). As multiple factors emerged from the data we conclude that common method bias did not overly influence our analyses.

We analysed the dynamics between farmers' attitudes and actions by investigating factors related to the actual (reported), rather than perceived, levels of human-carnivore conflict and carnivore removal. One important factor related to loss of livestock to carnivores is the impact of losses based on the type of livestock farmed. We calculated the percentage of livestock loss to carnivores across different types of livestock, and compared these to the percentage of livestock lost to all causes.

Multiple regression analysis was conducted using ordinary least squares regression. We compared regression models for goat, sheep and cattle farmers for the impact of independent variables of interest (herd size, livestock as a source of cash income and number of losses) against a base model that only included control variables. All the regression equations were statistically significant. We excluded a few outliers in the regressions for actual level of carnivore removals but also checked that the results held via a robustness test that included these outlier observations.

\section{Results}

Namibian emerging commercial farmers' attitudes towards carnivores

The majority of emerging commercial farmers (52.4\%) reported that carnivores are a 'big' or 'very big' problem. 
Carnivores were perceived as the greatest cause of livestock losses (31.0\%), above disease (19.0\%), poisonous plants $(18.0 \%)$, theft $(17.0 \%)$ or birthing problems (10.0\%). This is not surprising given that $86.4 \%$ of farmers reported livestock losses to carnivores. Farmers appeared familiar with carnivores, identifying species with $86-100 \%$ accuracy, with the exception of spotted and brown hyaenas, which were only correctly identified in half of the cases. When asked if they liked having carnivores on their farms, 39.0\% responded negatively versus $28.1 \%$ positively $\left(\chi^{2}=13.24\right.$, $\mathrm{df}=4, \mathrm{P}=0.010$ ).

Some $40.8 \%$ of farmers were keen to have all carnivores removed from their farmland $\left(\chi^{2}=11.28, \mathrm{df}=4, \mathrm{P}=0.024\right)$, and $32.1 \%$ of respondents believed the only way to reduce livestock loss is by removing all carnivores but this result is not statistically significant $\left(\chi^{2}=5.11, \mathrm{df}=4, \mathrm{P}=0.276\right)$. In contrast, farmers who viewed carnivores as having an ecological role on their farms $\left(48.0 \% ; \chi^{2}=13.85, \mathrm{df}=4\right.$, $\mathrm{P}=0.008$ ) were less likely to want all carnivores removed from farmland (Spearman's $\rho=-0.606, \mathrm{P}=0.010$ ). We assessed whether these attitudes towards carnivores were measuring the same thing, via a principal component analysis. The results (Table 1) show that all four items, whether affective or cognitive, captured one underlying attitude, as all four load together onto a single component. All loadings are well above the 0.5 cut-off point. Attitudes that were positive versus negative loaded in opposite directions, as a bipolar factor. Thus farmers who had a negative attitude towards carnivores wanted them removed from their land, believed the only way to reduce livestock losses is by removing carnivores, did not believe carnivores played an ecological role and disliked having carnivores on their farm. This suggests that, taken together, these items appropriately capture attitude towards carnivores.

\section{Perceived levels of human-carnivore conflict and intended action}

Some $75.8 \%$ of farmers stated they had a carnivore problem after several livestock kills were made, and $42.7 \%$ said they had a problem when one livestock kill was made, or when livestock returned home without offspring (44.0\%). Some $45.2 \%$ of farmers said they had a carnivore problem when game was killed on their farm, $56.1 \%$ of farmers stated carnivore problems were present when they sighted carnivore tracks, and $54.9 \%$ said they had a problem when sighting a carnivore.

In all presented scenarios there is a strong correlation between the perception of having a carnivore problem and the reported intention to remove carnivores. For example, $70.3 \%$ of farmers said they would be more likely to remove carnivores when several livestock were killed and less likely to do so when game was killed (40.3\%). There are significant and positive correlations between the perception of a
TABLE 2 Principal component analysis of the relationships between perceived levels of carnivore conflict and likelihood to remove carnivores. All four factors had Eigenvalues $>_{1}$ and a visual assessment of the scree plot confirmed that all components should be considered in the analysis. The four factors explained $68.3 \%$ of the variance. See text for further details.

\begin{tabular}{|c|c|c|c|c|}
\hline \multirow{2}{*}{$\begin{array}{l}\text { Items pertaining to the perception } \\
\text { of carnivore problems versus } \\
\text { action taken by respondents }\end{array}$} & \multicolumn{4}{|c|}{ Factor loadings } \\
\hline & 1 & 2 & 3 & 4 \\
\hline $\begin{array}{l}\text { Action taken when } \\
\text { carnivores are seen }\end{array}$ & 0.85 & 0.10 & 0.15 & -0.19 \\
\hline $\begin{array}{l}\text { Action taken when } \\
\text { carnivore tracks are seen }\end{array}$ & 0.76 & 0.17 & 0.23 & 0.06 \\
\hline $\begin{array}{l}\text { Problem when carnivores } \\
\text { are seen }\end{array}$ & 0.74 & 0.13 & 0.31 & 0.11 \\
\hline $\begin{array}{l}\text { Problem when carnivore } \\
\text { tracks are seen }\end{array}$ & 0.70 & 0.00 & 0.41 & 0.19 \\
\hline $\begin{array}{l}\text { Action taken when livestock } \\
\text { return without calves/kids }\end{array}$ & 0.23 & 0.87 & 0.07 & 0.02 \\
\hline $\begin{array}{l}\text { Action taken when several } \\
\text { livestock kills are made }\end{array}$ & -0.50 & 0.61 & 0.24 & -0.20 \\
\hline $\begin{array}{l}\text { Action taken when one } \\
\text { livestock kill is made }\end{array}$ & 0.56 & 0.59 & -0.12 & 0.17 \\
\hline $\begin{array}{l}\text { Problem when livestock } \\
\text { return without calves/kids }\end{array}$ & 0.16 & 0.55 & 0.40 & 0.29 \\
\hline $\begin{array}{l}\text { Problem when game killed } \\
\text { by carnivore }\end{array}$ & 0.33 & 0.07 & 0.71 & 0.06 \\
\hline $\begin{array}{l}\text { Action taken when game } \\
\text { killed by carnivore }\end{array}$ & 0.24 & 0.13 & 0.67 & -0.17 \\
\hline $\begin{array}{l}\text { Problem when several } \\
\text { livestock are killed }\end{array}$ & 0.06 & 0.01 & -0.17 & 0.81 \\
\hline $\begin{array}{l}\text { Problem when one livestock } \\
\text { kill is made }\end{array}$ & 0.00 & 0.17 & 0.51 & 0.65 \\
\hline
\end{tabular}

problem and action, as farmers stated they would remove carnivores when one livestock was killed (46.9\%), livestock returned without offspring (42.7\%), carnivores were sighted $(50.0 \%)$ or carnivore tracks were seen $(42.7 \%)$. The only exception was when several livestock were killed. Although this was most likely to result in farmers taking action, the correlation coefficient was not significant. We investigated these results and found they appeared to be affected by several outliers: six farmers said they would not take action even when several livestock were killed.

We tested to see if farmers distinguished between the perceived level of conflict and subsequent intention to take action, via a principal component analysis (Table 2). The level of conflict loads together with the intention to take action, suggesting that farmers view the problem and the solution as part of the same issue. In addition, it shows that farmers perceived sightings (carnivores, tracks), livestock loss and game loss as three separate issues. For example, items related to sighting a carnivore or carnivore tracks loaded together with the intention to take action. Similarly, sighting game killed and the intention to take action loaded onto a single factor. The link between the perceived level of 
TABLE 3 One-way Scheffe test comparing the percentage of livestock loss to carnivores and livestock loss to all causes between cattle, goats and sheep. The difference in the percentage of loss between types of livestock is indicated. Standard errors are given in parentheses.

\begin{tabular}{|c|c|c|c|c|c|c|}
\hline \multirow{2}{*}{$\begin{array}{l}\text { Livestock } \\
\text { type }\end{array}$} & \multirow{2}{*}{$\begin{array}{l}\% \text { loss to } \\
\text { carnivores }\end{array}$} & \multicolumn{2}{|l|}{ Difference } & \multirow{2}{*}{$\begin{array}{l}\% \text { loss to } \\
\text { all causes }\end{array}$} & \multicolumn{2}{|l|}{ Difference } \\
\hline & & Cattle & Goats & & Cattle & Goats \\
\hline$\overline{\text { Cattle }}$ & 0.91 & & & 4.31 & & \\
\hline Goats & 7.71 & $6.8^{* * *}$ & & 13.87 & $9.56^{\star \star \star}(2.33)$ & \\
\hline Sheep & 8.64 & $7.73^{\star \star \star}(1.63)$ & $0.93(1.66)$ & 15.78 & $11.47^{\star * \star}(2.41)$ & $1.91(2.46)$ \\
\hline
\end{tabular}

${ }^{\star} \mathrm{P}<0.05 ;{ }^{* *} \mathrm{P}<0.01 ;{ }^{* *} \mathrm{P}<0.001$

TABLE 4 Multiple regression analysis of factors influencing actual level of human-carnivore conflict, comparing regressions for goat, sheep and cattle farmers to the base regression that only included control variables. Regression 4 includes loss of calves as they are more susceptible to predators than adult cattle. Standard errors are given in parentheses.

\begin{tabular}{|c|c|c|c|c|}
\hline & $\begin{array}{l}\text { Regression } 1 \\
\text { (base) }\end{array}$ & $\begin{array}{l}\text { Regression } 2 \\
\text { (goat farmers) }\end{array}$ & $\begin{array}{l}\text { Regression } 3 \\
\text { (sheep farmers) }\end{array}$ & $\begin{array}{l}\text { Regression } 4 \\
\text { (cattle farmers) }\end{array}$ \\
\hline Constant & $5.258(3.197)$ & $4.114(3.090)$ & $2.374(3.353)$ & $3.667(4.130)$ \\
\hline Length of time on farm & $0.042(0.025)$ & $0.033(0.023)$ & $0.049(0.025)$ & $0.043(0.026)$ \\
\hline Longitude & $-0.158(0.115)$ & $-0.109(0.112)$ & $-0.013(0.123)$ & $-0.159(0.129)$ \\
\hline Latitude & $-0.023(0.108)$ & $0.022(0.103)$ & $-0.039(0.109)$ & $-0.025(0.122)$ \\
\hline Farm size & $-0.022(0.060)$ & $-0.019(0.059)$ & $-0.034(0.064)$ & $-0.039(0.066)$ \\
\hline Carnivore trend & $0.376^{*}(0.161)$ & $0.301(0.156)$ & $0.31(0.172)$ & $0.286(0.174)$ \\
\hline Attitude towards carnivores & $-0.087^{\star *}(0.026)$ & $-0.082^{\star \star}(0.026)$ & $-0.087^{\star \star}(0.028)$ & $-0.076^{\star \star}(0.027)$ \\
\hline Herd size & & $-0.004^{\star}(0.002)$ & $-0.003(0.002)$ & $0.001(0.002)$ \\
\hline Source of cash income & & $0.305(0.156)$ & $0.004(0.141)$ & $0.296(0.517)$ \\
\hline Livestock losses & & $0.055^{\star \star \star}(0.015)$ & $0.060^{\star *}(0.020)$ & $0.052(0.032)$ \\
\hline$R^{2}$ & 0.266 & 0.461 & 0.396 & 0.310 \\
\hline $\mathrm{n}$ & 74 & 64 & 62 & 68 \\
\hline
\end{tabular}

Two tailed t-tests: ${ }^{\star} \mathrm{P}<0.05 ;{ }^{* *} \mathrm{P}<0.01 ;{ }^{* * *} \mathrm{P}<0.001$

conflict and likelihood to take action is less clear in the case of livestock loss. Farmers distinguished between level of conflict when livestock are killed (Component 4), and the intention to take action when livestock are killed or return without their offspring (Component 2).

\section{Predictors of reported human-carnivore conflict and carnivore removal}

Although there was a difference in mean herd size for cattle $(150 \pm$ SD 68$)$ and small stock (216 \pm SD 124), carnivore predation had a greater effect on small stock than on cattle. Of all causes of cattle loss, $21.1 \%$ could be attributed to carnivores. The impact of carnivores on loss of small stock was much greater: $55.6 \%$ of all goat loss and $54.8 \%$ of all sheep loss was attributed to carnivores. The difference in the impact of losses (whether to carnivores or other causes) was statistically significant and much greater for small-stock loss than cattle loss (Table 3).

Because the impact of losses was felt more severely by small-stock farmers we expected that human-carnivore conflict levels and removal of carnivores would differ between small-stock and cattle farmers. We investigated these relationships via regression analysis. For actual levels of human-carnivore conflict the base model (Regression 1) explains $26.6 \%$ of variance and demonstrates that a negative attitude was significantly associated with carnivore conflict (Table 4). The variance explained increased to $46.1 \%$ for goat farmers, $39.6 \%$ for sheep farmers and $31.0 \%$ for cattle farmers. An increase in carnivore trend is positively associated with a negative attitude in the base model (Regression 1). However, this significant association disappears when other factors are accounted for (Regressions 2-4). There is a negative association between level of conflict and attitudes towards carnivores. In the case of goats having a smaller herd is significantly associated with the level of human-carnivore conflict. Livestock loss, particularly of small stock, is strongly associated with higher levels of human-carnivore conflict (Regressions 2 and 3) but loss of calves is not.

For the actual number of carnivores removed (Table 5) the variance explained by the regressions is lower than in the regressions for levels of human-carnivore conflict. The $R^{2}$ of the base model (Regression 1) is low but this increases substantially in Regressions 2-4, especially in the case of goat farmers. Goat loss is the only significant predictor of carnivore removal, and no other variables significantly predict actual levels of carnivore removal. 
TABLE 5 Multiple regression analysis of factors influencing actual levels of removals of carnivores, comparing regressions for goat, sheep and cattle farmers to the base regression that only included control variables. Five outliers were excluded from the regression. Standard errors are given in parentheses.

\begin{tabular}{lcccc}
\hline & $\begin{array}{l}\text { Regression 1 } \\
\text { (base) }\end{array}$ & $\begin{array}{l}\text { Regression 2 } \\
\text { (goat farmers) }\end{array}$ & $\begin{array}{l}\text { Regression 3 } \\
\text { (sheep farmers) }\end{array}$ & $\begin{array}{c}\text { Regression 4 } \\
\text { (cattle farmers) }\end{array}$ \\
\hline Constant & $-21.472(28.695)$ & $-16.863(29.501)$ & $6.621(33.778)$ & $17.485(35.637)$ \\
Length of time on farm & $0.320(0.223)$ & $0.198(0.219)$ & $0.246(0.251)$ & $0.300(0.226)$ \\
Longitude & $1.336(1.043)$ & $1.343(1.070)$ & $1.184(1.267)$ & $1.490(1.120)$ \\
Latitude & $0.088(0.976)$ & $-0.342(0.977)$ & $0.843(1.110)$ & $0.203(1.090)$ \\
Farm size & $0.446(0.533)$ & $0.755(0.547)$ & $0.317(0.652)$ & $0.348(0.580)$ \\
Carnivore trend & $0.589(1.414)$ & $-0.694(1.454)$ & $-0.009(0.278)$ & $0.223(1.512)$ \\
Carnivore attitude & $0.053(0.234)$ & $-0.039(0.245)$ & $0.018(0.018)$ & $0.121(0.244)$ \\
Herd size & & $-0.019(0.016)$ & $-2.474(1.392)$ & $0.007(0.018)$ \\
Source of cash income & & $-2.801(1.710)$ & $-0.057(0.230)$ & $-8.212(4.394)$ \\
Livestock losses & & $0.562^{\star * *}(0.158)$ & 0.172 & $0.443(0.277)$ \\
$R^{2}$ & 0.069 & 0.320 & 57 & 0.165 \\
$\mathrm{n}$ & 68 & 59 & & 65 \\
\hline
\end{tabular}

Two tailed t-tests: ${ }^{* *} \mathrm{P}<0.001$

\section{Discussion}

We found that overall the attitudes of the emerging commercial farmers do not differ markedly from other categories of farmers (Conover, 1994; Kellert et al., 1996; Marker, 2002). Negative attitudes towards carnivores prevail, with many farmers expressing the desire to have all carnivores removed from farmland. These negative attitudes were often associated with the perception of carnivores being a problem. In addition, there was a significant negative relationship between attitudes towards carnivores and level of conflict, indicating that when farmers have a more negative attitude towards carnivores they are also likely to perceive a higher level of carnivore conflict.

We also found that the perception of a problem seemed a sufficient motivator for farmers to want to remove carnivores from their land. In many cases simply seeing a carnivore or its tracks was perceived as a problem and farmers indicated they would take action against carnivores. Studies elsewhere corroborate this. Kellert et al. (1996) and Dickman (2005) found that attitudes towards carnivores are overshadowed by the perception of a problem and that this determines peoples' actions. Nonetheless, livestock losses, in particularly goat losses, were significant predictors of actual conflict. Our results are consistent with other results showing that humancarnivore conflict intensifies with livestock loss (Conover, 1994; Oli et al., 1994; Sillero-Zubiri \& Laurenson, 2001).

However, while livestock loss and negative attitudes towards carnivores predict higher levels of humancarnivore conflict, they did not predict actual removal of carnivores reported by farmers, except in the case of goat losses. This suggests that while farmers report their intention to remove carnivores they are not actually likely to remove them. When taking this into account together with the lack of correlation of several livestock killed and removing carnivores, we speculate that farmers who lose several livestock to carnivores lack the skills to manage livestock effectively, including the option to remove carnivores from their land. Verification of this could substantiate the need for training or provide further insights into conflict issues.

Perceived loss of livestock attributed to carnivores may be higher than the actual loss experienced by emerging commercial farmers, especially as they generally have little knowledge of carnivore behaviour and ecology and are not able to verify correctly the cause of livestock loss (Schumann \& Fabiano, 2006). Other studies confirm the tendency of farmers to exaggerate losses or attribute losses to carnivores regardless of whether or not the loss is a verified carnivore depredation (Oli et al., 1994; Marker et al., 1996; Rasmussen, 1999). This suggests that carnivores may be removed pre-emptively as a result of perceived cause of losses rather than identifying whether such losses are related to carnivore depredation. Animals perceived as incompatible with agricultural activities are often too easily condemned as problem animals when the real cause of the conflict is inappropriate livestock management (Bothma \& Glavovic, 1992; Marker et al., 1996; Schumann, 2006).

When livestock management practices are applied appropriately they often reduce livestock loss to carnivores. Indiscriminate removal tends to be counter-productive because it disrupts carnivore populations and actually increases the risk of further livestock loss (Marker et al., 1996; Ogada et al., 2003). Combining general knowledge training with management training is a potentially effective approach as people who are more knowledgeable about 
carnivores tend to be more tolerant (Caro et al., 2003; Treves \& Karanth, 2003). Our study shows that farmers who understood that carnivores play an ecological role had a more favourable attitude and were less likely to want all carnivores removed from their farms, and farmers that viewed carnivores more positively also perceived lower levels of conflict.

However, studies of formerly advantaged commercial farmers in Namibia found that even where farmers expressed tolerance towards large carnivores and recognized their ecological role, this did not necessarily result in lower removals of carnivores (Schumann et al., 2008). Lindsey et al. (2005) and Schumann et al. (2008) found that farmers who were members of conservancies were much more in favour of having a variety of carnivores on their land than non-conservancy members. This suggests that involvement with and education about conservation could nurture positive attitudes by reducing the perception of carnivore problems and thereby human-carnivore conflict.

We found that goat losses are not only a strong predictor of human-carnivore conflict but they are also a strong predictor of carnivore removals. Goat farmers appear to be more sensitive to livestock losses given that the loss of goats, especially, accounts for very negative attitudes towards carnivores, resulting in both higher levels of conflict and higher carnivore removals. This may be because goats are often the starting point of farm production and are an important source of income (Vigne \& Motinga, 2005). In the case of goats, having a smaller herd is significantly associated with the level of conflict with carnivores. Similarly, other studies have found that farmers with larger herd sizes were more able to absorb economic loss caused by livestock losses and were less inclined to have a negative attitude towards carnivores (Cozza et al., 1996; Dickman, 2005; Thirgood et al., 2005).

Cattle and calf losses did not appear to influence carnivore conflict or removal. This was unexpected as most emerging commercial farmers are weaner-calf producers (Vigne \& Motinga, 2005) and cow-calf operators typically experience more conflict than ox producers, given the vulnerability of calves to predation (Marker et al., 1996). Presumably this could change as emerging farmers move away from their dependence on small stock as a source of cash income to cattle production. Human-carnivore conflict mitigation strategies therefore need to be developed for emerging commercial farmers, not only emphasizing how to manage losses of small stock to reduce conflict but also livestock management of cattle as farmers diversify.

The impact of livestock losses on emerging commercial farmers is much greater than on formerly advantaged commercial farmers. In the case of formerly advantaged farmers $61 \%$ of their farms are $>7,000$ ha and $13 \%$ have a farm $>15,000$ ha (Marker et al., 1996). The mean farm size of the emerging commercial farmers in our study was 4,600 ha, with $90 \%$ of farms $<7,000$ ha. Formerly advantaged farmers have a mean cattle herd of 800 and small stock herd size of 597 (Marker et al., 1996) compared to the mean of 150 cattle and 216 small stock of emerging commercial farmers in our study. The latter lose $2.0 \%$ of cattle to carnivores compared to $1.1 \%$ for formerly advantaged farmers, and $9.0 \%$ of small stock compared to $6.5 \%$ for formerly advantaged farmers. In addition, mean loss data do not reflect the true extent of the impact in many cases, as losses are not equally distributed. Thus even where actual livestock losses are below perceived losses the impact on individual households can still be devastating (Oli et al., 1994; Cozza et al., 1996; Thirgood et al., 2005). In many cases the emerging commercial farmers may not be in as strong an economic position as formerly advantaged farmers to withstand the impacts of predation. Smaller herd sizes, relatively low calving percentages, reliance on small stock both as a source of cash income and sustenance, and a lack of diversity in farming production are all factors that exert pressure on emerging commercial farmers.

Whether the extent of a carnivore problem is real or perceived, removal of carnivores will continue if the underlying attitude of a broad spectrum of farmers is negative and the perceived level of conflict is high. Our work indicates the need for an interdisciplinary approach to combine conservation education with agricultural training. The challenge lies in moving the focus of farmers away from the removal of carnivores and towards pro-active livestock management techniques to reduce losses. This will require integrated interdisciplinary training in carnivore ecology and kill identification, to replace perceptions of loss with accurate verification, and training in livestock management to reduce losses to carnivores and other causes.

A sense of ownership over human-carnivore conflict and understanding the role of carnivores help build positive attitudes. By shaping perceptions, positive attitudes can be cultivated before the human-carnivore conflict escalates to a point where farmers become resentful and unwilling to work with the conservation sector. Some NGOs are taking an integrated approach to carnivore conservation training. Further research is needed to quantify the outcomes of this approach to determine if perceptions are being positively influenced and if the conflict is escalating, or not.

\section{Acknowledgements}

We would like to thank the Cheetah Conservation Fund (CCF) under the directorship of Dr Laurie Marker for making this study possible, the CCF staff, particularly Lorraine Bowden, Josephine Henghali and Gebhardt Nikanor for help with the surveys, Matti Nghikembua for his help with the map, and the emerging commercial farmers for their patience in sharing information. 


\section{References}

Bartholomew, D.J., Steele, F., Moustaki, I. \& Galbraith, J.I. (2002) The Analysis and Interpretation of Multivariate Data for Social Scientists. Chapman \& Hall/CRC, New York, USA.

BJERKe, T. \& KALTENBORN, B.P. (1999) The relationship of ecocentric and anthropocentric motives to attitudes toward large carnivores. Journal of Environmental Psychology, 19, 415-421.

BlackIE, R. (ed.) (1999) A Preliminary Environmental Assessment of Namibia's Resettlement Programme. Environmental and Geographical Science Master Students, University of Cape Town. Research Discussion Paper No. 32, Directorate of Environmental Affairs, Ministry of Environment and Tourism, Windhoek, Namibia.

Botнma, J.D.P. \& Glavovic, P.D. (1992) Wild animals. In Environmental Management in South Africa (eds R.F. Fuggle \& M.A. Rabie), pp. 250-276. Juta, Cape Town, South Africa.

Byers, B.A. (1997) Environmental Threats and Opportunities in Namibia: A Comprehensive Assessment. Research Discussion Paper No. 21, Directorate of Environmental Affairs, Ministry of Environment and Tourism, Windhoek, Namibia.

Caro, T., Borgerhoff Mulder, M. \& Moore, M. (2003) Effects of conservation education on reasons to conserve biological diversity. Biological Conservation, 114, 143-152.

Conover, M.R. (1994) Perceptions of grass-roots leaders of the agricultural community about wildlife damage on their farms and ranches. Wildlife Society Bulletin, 22, 94-100.

Conover, M.R. (2002) Resolving Human-Wildlife Conflicts: The Science of Wildlife Damage Management. CRC Press, Boca Raton, USA.

Cozza, K., Fico, R., Battistini, M. \& Rogers, E. (1996) The damage-conservation interface illustrated by predation on domestic livestock in central Italy. Biological Conservation, 78, 329-336.

Desert Research Foundation of Namibia (2005) Needs Assessment Study that Focuses on Government's Farm-Unit Resettlement Beneficiaries. TNA/RES/2004/o1 Final Report. Desert Research Foundation of Namibia, Windhoek, Namibia.

Dickman, A. (2005) An assessment of pastoralist attitudes and wildlife conflict in the Rungwa-Ruaha region, Tanzania, with particular reference to large carnivores. MSc thesis. University of Oxford, Oxford, UK

Dietz, T., Stern, P.C. \& Guagnano, G.A. (1998) Social structural and social psychological bases of environmental concern. Environment and Behavior, 30, 450-471.

Dillman, D.A. (1991) The design and administration of mail surveys. Annual Review of Sociology, 17, 225-249.

Edwards, A.L. (1994) Techniques of Attitude Scale Construction. Prentice Hall, New York, USA.

ERB, K.P. (2004) Consumptive wildlife utilisation as a land-use form in Namibia. MBA thesis. University of Stellenbosch, Stellenbosch, South Africa.

FodDy, W. (1993) Constructing Questions for Interviews and Questionnaires. Theory and Practice in Social Research. Cambridge University Press, Cambridge, UK.

Gagnon Thompson, S.C. \& Barton, M.A. (1994) Ecocentric and anthropocentric attitudes toward the environment. Journal of Environmental Psychology, 14, 149-157.

Gittleman, J.L., Funk, S.M., Macdonald, D.W. \& Wayne, R.K. (2001) Why "carnivore conservation"? In Carnivore Conservation (eds J.L. Gittleman, S.M. Funk, D.W. Macdonald \& R.K. Wayne), pp. 1-7. Cambridge University Press, Cambridge, UK.

Hanssen, L. \& Stander, P. (2004) Namibia Large Carnivore Atlas. Vol. 1. Http://www.predatorconservation.com [accessed 22 August 2007].
Hines, J.M., Hungerford, H.R. \& Tomera, A.N. (1987) Analysis and synthesis of research on responsible environmental behavior: a meta-analysis. Journal of Environmental Education, $18,1-18$.

JAMES, S.M. (2002) Bridging the gap between private landowners and conservationists. Conservation Biology, 16, 269-271.

Kaltenborn, B.P., Bjerke, T. \& Strumse, E. (1998) Diverging attitudes towards predators: do environmental beliefs play a part? Human Ecology Review, 5, 1-9.

Kellert, S.R. (1985) Public perceptions of predators, particularly the wolf and coyote. Biological Conservation, 31, 167-189.

Kellert, S.R. \& Berry, J.K. (1987) Attitudes, knowledge and behaviours towards wildlife as affected by gender. Wildlife Society Bulletin, 15, 363-371.

Kellert, S.R., Black, M., Rush, C.R. \& Bath, A.J. (1996) Human culture and large carnivore conservation in North America. Conservation Biology, 10, 977-990.

KRUGmann, H. (2001) Fundamental Issues and the Threats to Sustainable Development in Namibia. Research Discussion Paper No. 46. Directorate of Environmental Affairs, Ministry of Environment and Tourism, Windhoek, Namibia.

Lange, G.-M., Barnes, J.I. \& Motinga, D.J. (1997) Cattle Numbers, Biomass, Productivity and Land Degradation in the Commercial Farming Sector of Namibia, 1915-1995. Research Discussion Paper No. 17. Directorate of Environmental Affairs, Ministry of Environment and Tourism, Windhoek, Namibia.

Lindsey, P.A., DU Toit, J.T. \& Mills, M.G.L. (2005) Attitudes of ranchers towards African wild dogs Lycaon pictus: conservation implications on private land. Biological Conservation, 125, 113-121.

Marker, L. (2002) Aspects of cheetah (Acinonyx jubatus) biology, ecology and conservation strategies on Namibian farmlands. $\mathrm{PhD}$ thesis. University of Oxford, Oxford, UK.

Marker, L., Kraus, D., Barnett, D. \& Hurlbutt, S. (1996) Cheetah Survival on Namibian Farm Lands. Solitaire Press, Windhoek, Namibia.

Marker, L. \& SChumann, B.D. (1998) Cheetahs as problem animals: management of cheetahs on private land in Namibia. In Proceedings of a Symposium on Cheetahs as Game Ranch Animals (ed. B.L. Penzhorn), pp. 90-99. Wildlife Group of South African Veterinary Association, Onderstepoort, South Africa.

Miller, M.G. \& Tesser, A. (1986) Effects of affective and cognitive focus on the attitude-behavior relation. Journal of Personality and Social Psychology, 51, 270-276.

Ogada, M.O., Woodroffe, R., Oguge, N.O. \& Frank, L.G. (2003) Limiting depredation by African carnivores: the role of livestock husbandry. Conservation Biology, 17, 1521-1530.

Oli, M.K., Taylor, I.R. \& Rogers, M.E. (1994) Snow leopard Panthera uncia predation of livestock: an assessment of local perceptions in the Annapurna Conservation Area, Nepal. Biological Conservation, 68, 63-68.

Podsakoff, P.M., Mackensie, S.B. \& Lee, J.Y. (2003) Common method biases in behavioural research: a critical review of the literature and recommended remedies. Journal of Applied Psychology, 88, 879-903.

RASMUSSEN, G.S.A. (1999) Livestock predation by the painted hunting dog Lycaon pictus in a cattle ranching region of Zimbabwe: a case study. Biological Conservation, 88, 133-139.

Romañach, S.S., Lindsey, P.A. \& Woodroffe, R. (2007) Determinants of attitudes toward predators in central Kenya and suggestions for increasing tolerance in livestock dominated landscapes. Oryx, 41, 185-195.

Røskaft, E., Händel, B., Bjerke, T. \& Kaltenborn, B.P. (2007) Human attitudes towards large carnivores in Norway. Wildlife Biology, 13, 172-185. 
Sachikonye, L.M. (2004) Land reform in Namibia and Zimbabwe: a comparative perspective. In Who Should Own the Land? (ed. J. Hunter), pp. 64-82. John Meinert Printing, Windhoek, Namibia.

SChumann, B.D. \& Fabiano, E. (2006) Evaluation of Integrated Livestock and Predator Management Training Courses: Emerging Commercial Farmers. Unpublished Report to Cheetah Conservation Fund, Otjiwarongo, Namibia.

Schumann, M.E. (2006) Predator conflict resolution in Namibian conservancies, with special reference to the cheetah (Acinonyx jubatus). MTech thesis. Nelson Mandela Metropolitan University, Port Elizabeth, South Africa.

Schumann, M.E., Watson, L.H. \& Schumann, B.D. (2008) Attitudes of Namibian commercial farmers towards large carnivores: the influence of conservancy membership. South African Journal of Wildlife Research, 38, 123-132.

Sillero-Zubiri, C. \& Laurenson, M.K. (2001) Interactions between carnivores and local communities: conflict or co-existence? In Carnivore Conservation (eds J.L. Gittleman, S.M. Funk, D.W. Macdonald \& R.K. Wayne), pp. 282-312. Cambridge University Press, Cambridge, UK.

Stander, P.E., Llau, K., Lui, N., Dabe, T. \& Dabe, D. (1997) Nonconsumptive utilisation of leopards: community conservation and ecotourism in practice. In Proceedings of a Symposium on Lions and Leopards as Game Ranch Animals (ed. B.L. Penzhorn), pp. 50-57. Wildlife Group of South African Veterinary Association, Onderstepoort, South Africa.

Stern, P.C., Dietz, T. \& Kalof, L. (1993) Value orientations, gender, and environmental concern. Environment and Behavior, 25, 322-348.

Stern, P.C., Dietz, T., Kalof, L. \& Guagnano, G.A. (1995) Values, beliefs, and pro-environmental action: attitude formation toward emergent attitude objects. Journal of Applied Social Psychology, 25, $1611-1636$.
Strohbach-Fricke, M. (1997) Exciting world of Namibian Flora. In Namibia Environment (ed. P. Tarr), pp. 32-49. Vol. 1. Directorate of Environmental Affairs, Ministry of Environment and Tourism, Windhoek, Namibia.

Thirgood, S., Woodroffe, R. \& Rabinowitz, A. (2005) The impact of human-wildlife conflict on human lives and livelihoods. In People and Wildlife: Conflict or Coexistence? (eds R. Woodroffe,

S. Thirgood \& A. Rabinowitz), pp. 13-26. Cambridge University Press, Cambridge, UK.

Thurstone, L.L. (1928) Attitudes can be measured. American Journal of Sociology, 33, 529-544.

Thurstone, L.L. (1946) Comment. American Journal of Sociology, 52, $39-50$.

Treves, A. \& Karanth, U. (2003) Human-carnivore conflict and perspectives on carnivore management worldwide. Conservation Biology, 17, 1491-1499.

Vigne, P. \& Motinga, D. (2005) Assessing Training Needs among AALS Farmers: Cash and Skills needed to Farm Successfully in Namibia. Research Report 7. Institute for Public Policy Research, Windhoek, Namibia.

Woodroffe, R. (2001) Strategies for carnivore conservation: lessons from contemporary extinctions. In Carnivore Conservation (eds J.L. Gittleman, S.M. Funk, D.W. Macdonald \& R.K. Wayne), pp. 61-92. Cambridge University Press, Cambridge, UK.

\section{Biographical sketches}

Bonnie Schumann is interested in carnivore conservation, with a particular focus on resolution of human-carnivore conflicts occurring outside protected areas. JUDITH WALLS is interested in the human aspects of conservation and looks at the role of individuals and businesses in environmental management. VICTOR HARLEY is an environmental consultant with diverse interests ranging from wildlife monitoring and census to sustainable agriculture and best practice. 